\title{
Peranan Pemimpin dalam Pembangunan Masyarakat Papua di Kabupaten Jayawijaya Papua
}

\author{
Soltan Takdir ${ }^{1}$, Muhammad $\mathrm{Ali}^{2}$ \\ ${ }^{1}$ STISIP Amal Ilmiah Yapis Wamena, Email : suletakdir1983@gmail.com \\ ${ }^{2}$ STISIP Amal Ilmiah Yapis Wamena, Email : Muhammadali_stisip@gmail.com
}

\begin{abstract}
Abstraksi
Otonomi Khusus bagi Provinsi Papua pada dasarnya adalah pemberian kewenangan yang lebih luas bagi Provinsi dan Rakyat Papua untuk mengatur dan mengurus diri sendiri di dalam kerangka Negara Kesatuan Republik Indonesia. Pelaksanaan program pembangunan masyarakat dengan melalui tahapan - tahapan dapat berjalan dengan lancar apabila pemimpin melaksanakan peranannya mengelola dirinya sendiri serta kelompok / masyarakat untuk bersama - sama bergerak dan mau melaksanakan program pembangunan masyarakat. Pemimpin memiliki 2 (dua) fungsi utama dalam melaksanakan program pembangunan masyarakat yaitu fungsi yang berhubungan dengan tugas (task related) atau pemecahan masalah dan fungsi pemeliharaan kelompok (group maintenance). Peranan pemimpin dalam pembangunan masyarakat diantaranya Peranan hubungan antar pribadi (interpersonal role) yang diwujudkan dalam peranan sebagai figurehead, pemimpin dan pejabat perantara (liaison manager) Peranan yang berhubungan dengan informasi (informasional role) yang diwujudkan dalam peranan sebagai pemantau (monitor), sebagai pembagi informasi (disseminator), dan juru bicara (spokesman). Peranan pembuat keputusan (Decision role) yang diwujudkan dalam peranan sebagai wirausaha (entrepreneur), penghalau gangguan (disturbance handler), pembagi sumber daya (resource alligator) dan sebagai perunding (negosiator).
\end{abstract}

Kata Kunci : Peran Pemimpin, Pembangunan Masyarakat.

\section{Pendahuluan}

Pada tanggal 21 November 2001 Pemerintah Republik Indonesia telah mengesahkan UU No.21 Tahun 2001 tentang Otonomi Khusus bagi Provinsi Papua. Provinsi yang memiliki wilayah yang luas $421.981 \mathrm{~km}^{2}$, terdiri atas $12 \mathrm{kota}$, serta memiliki keragaman suku dan lebih dari 250 bahasa. Dengan adanya Otonomi khusus sedikitnya akan memberikan gairah baru dengan suasana kemerdekaan dalam hati dan jiwa orang Papua yang selama ini terus tertekan oleh berbagai persoalan pembangunan yang jauh tertinggal dengan provinsi - propinsi di Indonesia. Berbagai data pun menguatkan hal ini. Misalnya tingkat kemiskinan, dari data Badan Pusat Statistik (BPS) tahun 2000 lalu menempatkan propinsi Papua sebagai propinsi yang terbanyak penduduk miskinnya. Ironisnya merujuk pada Produk Domestik Regional Bruto (PDRB) perkapita wilayah, Papua menduduki urutan keempat di Indonesia.

Otonomi Khusus bagi Provinsi Papua pada dasarnya adalah pemberian kewenangan yang lebih luas bagi Provinsi dan Rakyat Papua untuk mengatur dan mengurus diri sendiri di dalam kerangka Negara Kesatuan Republik Indonesia. Kewenangan yang lebih luas berarti pula tanggung Jawab yang lebih besar bagi provinsi dan rakyat Papua untuk menyelenggarakan pemerintahan dan mengatur pemanfaatan kekayaan alam di provinsi 
Papua untuk sebesar - besarnya bagi kemakmuran rakyat Papua sebagai bagian dari rakyat Indonesia sesuai dengan peraturan perundang - undangan yang berlaku.

Dalam makalah ini penulis ingin menggali lebih dalam permasalahan yang terjadi di Propinsi Papua . Berdasarkan pasal 3 ayat 4 UU Republik Indonesia Nomor 21 tahun 2001 "Pembentukan, pemekaran, penghapusan, dan/atau penggabungan Kabupaten/Kota, ditetapkan dengan Undang - Undang atas usul Provinsi Papua.' Propinsi Papua hingga mendekati 1 Dasawarsa ini sejak diberlakukannya Otonomi Khusus ini telah terjadi pemekaran - pemekaran daerah baik dari tingkat propinsi maupun Kabupaten / Kotamadya diantaranya Propinsi Papua menjadi Propinsi Papua dan Propinsi Papua Barat. Untuk Papua sendiri saat ini terdiri atas 2 (dua) Kotamadya dan 12 (dua belas) Kabupaten sedangkan Propinsi Papua Barat terdiri atas 1 (satu) Kotamadya dan 8 (delapan) Kabupaten.

Dengan terjadinya perubahan pada pembagian - pembagian daerah pemerintahan tentu akan mempengaruhi pada perubahan - perubahan yang terjadi pada perangkat dan kepegawaian serta tugas dan kewenangan . Kemampuan prakarsa dan kreativitas perangkat dan kepegawaian akan terpacu, sehingga kapabilitas dalam mengatasi berbagai masalah domestik akan semakin kuat.

Salah satu harapan dikeluarkannya undang - undang No. 32 Tahun 2004, tentang Pemerintahan Daerah, yaitu meletakkan dasar-dasar administrasi Pemerintahan Desa sehingga baik para pemimpin formal (Kepala Desa dan Pamong Desa), maupun para pemimpin informal (Kepala Suku, Pdt / Pastor dan para Tokoh) semakin tahu dan mampu menjadi pelopor dalam masyarakat, terutama dalam fungsi mereka sebagai jembatan yang menghubungkan antara kemauan pemerintah dan kepentingan masyarakat, maupun kepentingan masyarakat yang satu dengan masyarakat yang lainnya. Dalam fungsi demikian mereka menjandang beban mencerna dan menerangkan kebijaksanaan - kebijaksanaan umum dan prioritas pembangunan yang dirancang oleh pemerintah kemudian menjelaskannya ke segenap anggota masyarakat. (Kogoya, 2013:1)

Oleh sebab itu, untuk melaksanakan fungsi dan peran seorang pemimpin, dibutuhkan jiwa kepemimpinan yang tentu berbeda dari yang selama ini dijalankan. Dibutuhkan pengetahuan teori - teori peranan dan fungsi yang terbarukan dengan harapan target dan tujuan dari Otonomi khusus ini dapat terlaksana dengan baik dan berkelanjutan untuk peningkatan taraf hidup masyarakat Papua secara menyeluruh sehingga pembangunan masyarakat dapat berjalan dengan baik.

Dalam membahas permasalahan ini penulis menggunakan metode penulisan referensi kajian kepemimpinan dan diramu dengan fakta yang terjadi dimasyarakat Papua khususnya Kabupaten Jayawijaya

2. Kajian Pustaka

a. Defenisi Pemimpin dan Kepemimpinan

Konsep "pemimpin" berasal dari kata asing leader dan kepemimpinan berasal dari kata leadership. Bennis dalam Pasolong (2010 : 2) mengatakan bahwa pemimpin adalah orang yang paling berorientasi hasil di dunia, dan kepastian dengan hasil ini hanya positif kalau seseorang mengetahui apa yang diinginkannya. Menurut Fairchild dalam Pasolong (2010 :2) mengatakan bahwa pemimpin dalam arti luas adalah seseorang yang memimpin, dengan jalan memprakarsai tingkah laku sosial dengan mengatur, menunjukkann, mengorganisasikan atau mengontrol usaha (upaya) orang lain atau melalui prestise, kekuasaan atau posisi. Sedangkan menurut Rivai dalam Pasolong (2010 : 2) menyatakan bahwa pemimpin adalah anggota dari suatu perkumpulan yang diberi kedudukan tertentu dan diharapkan dapat bertindak sesuai kedudukannya. Berdasarkan penjelasan para ahli diatas dapat dipahami bahwa pemimpin adalah seseorang yang berasal dari suatu perkumpulan atau organisasi itu sendiri yang 
diberikan kekuasaan untuk memimpin dengan menjalankan fungsi untuk mengatur, mengorganisasikan atau mengontrol kegiatan dalam mewujudkan hasil yang diinginkan.

Pengertian Kepemimpinan menurut Yulk dalam Aisyah dan Takdir (2017 : 121) Kepemimpinan adalah perilaku dari seseorang individu yang memimpin aktivitas-aktivitas suatu kelompok ke suatu tujuan yang hendak dicapai bersama. Griffin dalam Sule dan Saefullah (2010 : 255) membagi dalam 2 konsep yaitu sebagai proses dimana para pemimpin menggunakan pengaruhnya untuk memperjelas tujuan organisasi bagi para pegawai, bawahan, atau yang dipimpinnya, memotivasi mereka untuk mencapai tujuan tersebut, serta membantu menciptakan suatu budaya produktif dalam organisasi.

Adapun dari sisi atribut diartikan sebagai pemimpin yang memiliki kemampuan untuk mempengaruhi perilaku orang lain tanpa menggunakan kekuatan, sehingga orang - orang yang dipimpinnya menerima dirinya sebagai sosok yang layak memimpin mereka. Pendapat ini sejalan dengan pengertian yang disampaikan Thoha (2006 : 9) kepemimpinan adalah kegiatan untuk mempengaruhi perilaku orang lain, atau seni mempengaruhi perilaku manusia baik perorangan maupun kelompok.menurut Stoner dalam Handoko (2011 : 294) kepemimpinan manajerial sebagai suatu proses pengarahan dan pemberian pengaruh pada kegiatan - kegiatan dari sekelompok anggota yang saling berhubungan tugasnya. Dari pendapat diatas dapat dipahami bahwa kepemimpinan tidak terbatas pada suatu organisasi atau instansi saja, bisa terjadi pada siapa saja asalkan mereka memiliki kemampuannya untuk mempengaruhi perilaku orang lain kearah tercapainya suatu tujuan.

Memperhatikan pendapat para ahli dapat dipahami bahwa terdapat perbedaan mendasar antara pemimpin dan kepemimpinan yaitu pemimpin (leader) adalah seseorang yang melaksanakan perannya dalam menjalankan kepemimpinan (leadership).

b. Peranan Pemimpin

Menurut Suwandi (2004) dalam Tjandra dan Setiawati (2014) ada seorang ahli riset ilmu manajemen yang bernama Henry Mintzberg yang mengemukakan bahwa ada sepuluh peran yang dimainkan pemimpin di tempat kerjanya. Peran pemimpin dalam sebuah organisasi telah dikembangkan oleh Henry Minztberg dalam sebuah taksonomi dari 10 (sepuluh) peranan pemimpin yang digunakan untuk memodifikasi arti dan aktivitas - aktivitas yang diamati dalam studi mengenai para pemimpin. Kesepuluh peranan tersebut menerangkan semua kegiatan dari seorang manajer, dan tiap - tiap kegiatan dapat dijelaskan dalam kaitannya dengan paling sedikit satu peran, meskipun banyak aktivitas menyangkut lebih dari sebuah peran. 3 (tiga) peran berhubungan dengan perilaku antar pribadi dari para pemimpin, 3 (tiga) peran berhubungan dengan perilaku pemrosesan informasi dan 4 (empat) peran berhubungan dengan perilaku pengambilan keputusan. Menurut Henry Minzberg dalam Thoha ( $2006: 12$ ) peranan pemimpin antara lain :

1. Peranan hubungan antarpribadi (Interpersonal Role)

Dalam mewujudkan peranan ini ada dua gambaran umum yang dapat dilaksanakan yakni yang bertalian dengan status dan otoritas pemimpin, serta hal - hal yang bertalian dengan pengembangan hubungan antar pribadi. Peranan ini oleh Henry Minztberg dibagi atas tiga peranan yaitu :

Peranan sebagai figurehead, menurut Gary Yukl (1998 : 24) sebagai konsekuensi dari kewenangan formal mereka sebagai kepala dari sebuah organisasi atau dari salah satu sub unitnya, para pimpinan diharuskan untuk melakukan tugas - tugas simbolik tertentu yang bersifat legal dan sosial. Tugas - tugas tersebut termasuk diantaranya menandatangani dokumen - dokumen, memimpin pertemuan - pertemuan tertentu dan peristiwa peristiwa seremonial ( misalnya jamuan perpisahan , upacara - upacara pembukaan, peresmian, pengguntingan pita, pemukulan gong). Pemimpin harus berpartisipasi dalam 
kegiatan - kegiatan tersebut meskipun ia hanya mempunyai kepentingan yang marginal saja dalam pekerjaan mengelola.

Peranan sebagai pemimpin (leader), Menurut Thoha (2006 : 13) dalam peranan ini pemimpin melakukan hubungan interpersonal dengan yang dipimpin, dengan melakukan fungsi - fungsi pokoknya diantaranya memimpin, memotivasi, mengembangkan dan mengendalikan. Sejumlah kegiatan yang memperhatikan peranan pemimpin ini termasuk pula merekrut, melatih, mengarahkan, memberi pujian, memberi kritik, mempromosikan, dan memberhentikan. Dalam organisasi informal biasanya pemimpin diikuti karena mempunyai kekuasaan karismatik atau kekuasaan fisik. Adapun dalam organisasi formal, pemimpin yang diangkat dari atas, sering kali tergantung akan kekuasaan yang melekat pada jabatannya tersebut.

Peranan sebagai pejabat perantara (liaison manager), menurut Thoha (2006:13) dalam peranan ini pemimpin melakukan peranan yang berinteraksi dengan teman sejawat, staf, dan orang lain yang berada diluar organisasinya, untuk mendapatkan informasi. Hakikat dari peran pejabat perantara adalah membuat kontak - kontak baru, tetap menjalin hubungan dan memberi bantuan yang sebaliknya akan memungkinkan pimpinan tersebut untuk pada saatnya meminta juga kemurahan hati orang lain.

2. Peranan yang berhubungan dengan Informasi (informasional Role)

Sebagai seorang pemimpin yang menggerakkan sebuah organisasi maka dibutuhkan informasi - informasi yang penting dalam menjalankan keberlangsungan sebuah organisasi tersebut agar dapat bekerja secara efektif dan efisien untuk mewujudkan visi misi organisasi. Oleh karena itu sebagai kelanjutan dari peranan hubungan antarpribadi (interpersonal role). Henry Minztberg merancang peranan kedua yakni yang berhubungan dengan informasi. Peranan ini terdiri dari peranan - peranan sebagai berikut :

Peran sebagai pemantau (monitor), menurut Gary Yukl (1998 : 25) para pemimpin secara kontinu mencari informasi dari sejumlah sumber, seperti membaca laporan laporan dan memo, hadir dalam pertemuan - pertemuan dan pengarahan serta melakukan perjalanan pengamatan. Kebanyakan dari informasi tersebut dianalisis untuk menemukan masalah - masalah dan peluang - peluang, dan untuk mengembangkan pengertian mengenai peristiwa - peristiwa luar serta proses - proses internal di dalam sub unit organisasi dari pemimpin tersebut.

Peranan sebagai disseminator (Pembagi informasi), menurut Gary Yukl (1998 : 25) para pemimpin mempunyai akses khusus kepada sumber - sumber informasi yang tidak tersedia bagi bawahan. Beberapa dari informasi tersebut bersifat aktual dan beberapa diantaranya berhubungan dengan preferensi dari para individu yang ingin mempengaruhi pemimpin tersebut. Beberapa informasi tersebut harus diteruskan kepada para bawahan, mungkin dalam bentuk aslinya atau setelah diinterpretasi dan disunting oleh pemimpin tersebut.

Peranan sebagai juru bicara (spokesman), menurut Thoha (2006 : 16) sebagai juru bicara (spokesman) secara formal pemimpin mewakili atau bertindak atas nama organisasinya, sebagai pemimpin mereka merupakan pusat informasi, yang mengetahui banyak tentang organisasinya. Untuk itu mereka bertindak efektif dalam mewakili organisasinya.

3. Peranan pembuat keputusan (decision role)

Salah satu peranan yang paling rumit buat pemimpin adalah bagaimana pemimpin dapat terlibat langsung dalam pengambilan keputusan agar organisasi dapat berjalan sesuai visi misi yang telah ditentukan. Henry Mintzberg dalam Thoha (2006 : 17) berkesimpulan bahwa sebagian besar tugas pemimpin pada hakikatnya digunakan secara penuh untuk memikirkan sistem pembuatan strategi organisasinya. 
Keterlibatan pemimpin dalam pengambilan keputusan disebabkan karena : (1) secara otoritas yang formal pemimpin adalah satu - satunya yang diperbolehkan terlibat untuk memikirkan tindakan - tindakan yang penting atau yang baru dalam organisasinya; (2) sebagai pusat informasi, pemimpin dapat memberikan jaminan atas keputusan yang terbaik, yang mencerminkan pengetahuan yang terbaru dan nilai - nilai organisasi; (3) keputusan - keputusan strategis akan lebih mudah diambil secara terpadu dengan adanya satu orang yang dapat melakukan kontrol atas semua kegiatan operasional organisasi.

Ada 4 (empat) peranan pemimpin yang dikelompokkan ke dalam peranan pengambilan keputusan diantaranya Peran sebagai Wirausahawan (entrepreneur), meskipun istilah entrepreneur berasal dari ahli - ahli ekonomi tetapi ada perbedaan mendasar yang dimaksudkan Henry Minztberg. Menurut Thoha (2006 : 18) kalau ahli ekonomi cenderung memusatkan pada pekerjaan - pekerjaan awal dari organisasi baru, maka Henry Mintzberg memusatkan pada semua pekerjaan - pekerjaan managerial yang dihubungkan dengan perubahan - perubahan yang sistematis dalam organisasi yang sedang berjalan termasuk organisasi baru. Menurut Gary Yukl (1998 : 25) Pemimpin sebuah organisasi atau sub unitnya bertindak sebagai pemrakarsa dan perancang perubahan yang terkendali untuk memanfaatkan peluang - peluang dalam memperbaiki situasi yang sekarang ada. Perubahan yang terencana terjadi dalam bentuk proyek - proyek perbaikan seperti pengembangan sebuah produk baru, pembelian peralatan baru, atau reorganisasi formal.

Peranan sebagai penghalau gangguan (disturbance handler), menurut Gary Yukl (1998 : 25) dalam peran sebagai penangan kerusuhan atau kesukaran, seorang pemimpin menghadapi krisis yang mendadak yang tidak dapat diabaikan, yang berbeda dengan masalah - masalah yang dipecahkan secara sukarela oleh pemimpin tersebut agar dapat memafaatkan peluang - peluang yang ada. Krisis tersebut disebabkan oleh peristiwa peristiwa yang tidak diduga seperti konflik bawahan, kehilangan seorang bawahan penting, kebakaran atau kecelakaan, pemogokan, dan lain sebagainya. Seorang pemimpin secara khas memberikan prioritas terhadap peran tersebut dibanding dengan yang lainnya.

Peran sebagai pembagi sumber daya (resource alligator), para pemimpin menggunakan kekuasaan mereka untuk mengalokasi sumber - sumber daya yang dimiliki organisasi baik dana, personalia, material, peralatan, fasilitas - fasilitas, dan jasa - jasa. Menurut Thoha (2006 : 19) membagi sumber daya adalah suatu proses pembuatan keputusan. Peranan ini memutuskan kemana sumber daya akan didistribusikan ke bagian - bagian dari organisasi yang dipimpinnya. Strategi harus ditetapkan, pandangan - pandangan yang jauh dan positif harus dilihat pemimpin, sehingga alokasi sumber daya dapat diberikan sebaik mingkin.

Peran sebagai perunding (negosiator), menurut Gary Yukl (1998 : 26) perundingan apapun yang membutuhkan suatu komitmen yang substansial dari sumber - sumber daya akan dibantu oleh kehadiran seorang pemimpin yang mempunyai kekuasaan untuk membuat komitmen tersebut. Para pemimpin dapat ikut serta dalam berbagai jenis perundingan, termasuk perundingan dengan serikat pekerja yang menyangkut kontrak antara buruh dan manajemen atau mengenai tuntutan buruh.

c. Pembangunan Masyarakat

Pembangunan merupakan kata kunci dalam segala hal, perkembangan Indonesia selalu di identikkan dengan seberapa besar pembangunan yang dilaksanakan masyarkat Indonesia. Menurut Budiman (1995 : 1) secara umum pembangunan diartikan sebagai usaha untuk memajukan kehidupan masyarakat dan warganya ; seringkali kemajuan yang dimaksudkan terutama adalah kemajuan dari sisi material saja. Sedangkan menurut Djojonegoro (1996 : 7) pembangunan pada hakekatnya adalah suatu proses transformasi masyarakat dari suatu keadaan pada keadaan lain yang makin mendekati tata masyarakat 
yang dicita - citakan ; dalam proses transformasi itu ada 2 (dua) hal yang perlu diperhatikan, yaitu keberlanjutan (continuity) dan perubahan (change), tarikan antar keduanya menimbulkan dinamika dalam perkembangan masyarakat.

Menurut Adisasmita (2006 : 115) Pembangunan masyarakat dilakukan berdasar 3 (tiga) azas yaitu :

1. Azas pembangunan integral adalah pembangunan yang seimbang dilihat dari segi / unsur masyarakat dari semua sektor pembangunan,

2. Azas kekuatan sendiri adalah tiap usaha harus didasarkan pada kekuatan atau kemampuan masyarakat itu sendiri, artinya tidak terlalu mengharapkan pemberian bantuan dari pemerintah,

3. Azas pemufakatan bersama diartikan bahwa usaha pembangunan harus dilaksanakan pada bidang atau sektor yang benar - benar dirasakan sebagai kebutuhan bagi masyarakat yang bersangkutan.

3. Pembahasan

Pembangunan Masyarakat tidak dapat dipisahkan dengan peran serta seorang pemimpin. Sebagai tokoh utama dalam kegiatan - kegiatan dimasyarakat, pemimpin memiliki peran dalam merencanakan, mengatur dan mengorganisasikan atau mengontrol kegiatan dalam mewujudkan hasil dari pembangunan masyarakat yang diinginkan .

Dalam menjalankan perannya, seorang pemimpin memiliki 2 (dua) fungsi utama dalam melaksanakan program pembangunan masyarakat diantaranya :

a. Fungsi yang berhubungan dengan tugas (task related) atau pemecahan masalah.

Seorang pemimpin memiliki fungsi dalam pemberian saran, informasi dan pendapat dalam mewujudkan pembangunan masyarakat. Karena, dengan saran, informasi dan pendapat seorang pemimpin sebagai salah satu bukti wujud perhatian pemimpin terhadap pelayanan masyarakat.

b. Fungsi yang berhubungan dengan fungsi pemeliharaan kelompok (group maintenance) atau sosial.

Dalam menjalankan fungsi pemeliharaan kelompok / masyarakat mencakup di dalamnya segala sesuatu yang dapat membantu kelompok / masyarakat agar pelaksanaan pembangunan masyarakat berjalan lebih lancar. Tidak tinggal diam melihat kegiatan kegiatan yang dilaksanakan oleh masyarakat tetapi ikut berperan serta dan menjadi penggerak utama dalam menyukseskan kegiatan yang dilaksanakan oleh masyarakat tersebut.

Tahapan - Tahapan yang dapat ditempuh seorang pemimpin dalam mewujudkan Pembangunan masyarakat diantaranya :

1. Perencanaan

Seorang Pemimpin dalam menjalankan suatu kegiatan yang berorientasi pada pembangunan masyarakat adalah melaksanakan perencanaan bersama masyarakat. Perencanaan merupakan hal yang sangat urgen dan merupakan sarana bagi pemimpin untuk menentukan kearah mana pembangunan dapat dijalankan.

Pelaksanaan perencanaan pembangunan masyarakat sebaiknya melalui mekanisme perencanaan bottom up yang berasal dari akar rumput bawah dengan mengikutsertakan partisipasi masyarakat sebagai salah satu wujud pemberdayaan masyarakat (Social Empowering) secara nyata dan terarah. Pelaksanaan perencanaan pembangunan masyarakat tetap berlandaskan pada azas pembangunan diantaranya :

a. Azas pembangunan integral yang berlandaskan pada keseimbangan pembangunan segala arah dan tepat sasaran berdasarkan kebutuhan masyarakat itu sendiri.

b. Azas Kekuatan sendiri dan tidak terlalu mengharapkan pada bantuan pemerintah atau pihak swasta yang tidak sejalan dengan keinginan masyarakat. Pada Azas ini 
sangat perlu ditekankan kepada masyarakat karena realita di lapangan, pembangunan yang dilaksanakan masyarakat sangat tergantung oleh bantuan pemerintah, sedangkan telah kita pahami bersama bahwa anggaran pemerintah dalam mengalokasikan pembangunan tidaklah mencukupi untuk melaksanakan pembangunan secara menyeluruh. Ketergantungan pada pemerintah juga berakibat kurangnya kreativitas pemimpin dan masyarakat dalam mencari solusi pendanaan dalam mewujudkan pembangunan masyarakat seutuhnya.

c. Azas pemufakatan dapat diartikan bahwa pembangunan harus dilaksanakan pada bagian - bagian yang diprioritaskan dan benar - benar dapat dirasakan sebagai kebutuhan masyarakat yang dapat meningkatkan kesejahteraan masyarakat itu sendiri. Azas ini perlu dipertimbangkan dengan seksama karena terlihat dilapangan begitu banyak pembangunan yang ada dimasyarakat yang tidak tepat sasaran bukanlah hal yang sangat dibutuhkan masyarakat pada saat ini sehingga hasil pembangunan tersebut tidak memiliki dampak yang besar buat masyarakat sekitarnya.

2. Pengorganisasian

Setelah perencanaan terlaksana dengan baik dan telah dianalisis kelayakan dalam program yang akan dibuat, maka seorang pemimpin melaksanakan konsep pengorganisasian yang baik.

Konsep pengorganisasian memiliki makna yang cukup luas karena pada prinsipnya menyangkut 2 (dua) fungsi yang berbeda, yaitu :

a. Pembuatan struktur organisasi sebagai wadah melaksanakan program pembangunan. Dalam pembuatan struktur organisasi haruslah mempertimbangkan segala aspek yang akan dilaksanakan sehingga program pembangunan tersebut berjalan dengan baik dan tiap anggota struktur tersebut melaksanakan tugasnya sehingga tidak terjadi tumpang tindih terhadap tugas masing - masing anggota untuk menjalankan program pembangunan yang akan dilaksanakan.

b. Penempatan kelompok / masyarakat dalam pelaksanaan tugas berdasarkan bagan organisasi yang telah dibuat sebelumnya. Kapabilitas pemimpin akan teruji dalam tugas penempatan kelompok / masyarakat dalam struktur organisasi tersebut sehingga disarankan pemimpin harus mengetahui lebih dulu tentang karakteristik orang yang akan ditempatkan sebaik mungkin, guna mendapatkan orang yang tepat pada pekerjaan yang tepat (The right man on the right place at the right time) sekaligus menggunakan gaya kepemimpinan yang tepat pada situasi bawahan yang tepat.

3. Pengawasan

Pengawasan sebagai salah satu wujud tugas dari seorang pemimpin yang perlu diperhatikan, setelah perencanaan dan pengorganisasian berjalan dengan baik dan telah mendapatkan gambaran jelas pelaksanaan program pembangunan masyarakat dan alokasi anggaran telah tercairkan maka kegiatan pemimpin adalah mengawasi segala hal dalam pelaksanaan pembangunan tersebut.

Pada dasarnya pemimpin dalam mengawasi pembangunan yang sementara berjalan sangat memperhatikan pada 3 (tiga) hal yaitu anggaran yang dikelola, bahan dan peralatan yang dipergunakan serta sumber daya manusia yang mengelola program pembangunan tersebut sehingga kegiatan yang dilaksanakan berdasarkan standar yang telah disepakati bersama pada pelaksanaan perencanaan, ukuran hasil atas dasar standar tersebut dan memberikan rekomendasi dan arahan perbaikan jika program pembangunan yang berjalan tidak sesuai dengan standar yang ada.

4. Evaluasi Kegiatan 
Pengevaluasian program pembangunan yang telah dilaksanakan sebagai tahapan yang tetap dilaksanakan dengan baik. Pemimpin bersama masyarakat melakukan evaluasi terhadap pelaksanaan pekerjaan yang telah dilakukan, apakah pelaksanaan program tersebut berjalan secara efisien dan efektif serta menjadi bahan pertimbangan bagi pemimpin dan masyarakat terhadap hal - hal yang tidak sesuai dengan harapan dan keinginan masyarakat untuk melaksanakan program - program pembangunan yang lainnya.

Pelaksanaan program pembangunan masyarakat dengan melalui tahapan - tahapan diatas dapat berjalan dengan lancar apabila pemimpin melaksanakan peranannya mengelola dirinya sendiri serta kelompok / masyarakat untuk bersama - sama bergerak dan mau melaksanakan program pembangunan masyarakat.

Beberapa peranan pemimpin yang dapat dijalankan diantaranya :

1. Peranan hubungan antar pribadi (interpersonal role)

Dalam mewujudkan program pembangunan masyarakat ada 2 (dua) penjelasan umum yang dapat dilaksanakan yakni yang bertalian dengan status dan otoritas seorang pemimpin. Dengan status dan otoritas ini sebagai alat utama seorang pemimpin dapat menjalankan dan mengarahkan segala hal yang berkaitan dengan program - program pembangunan masyarakat. Serta hal - hal yang bertalian dengan pengembangan hubungan antar pribadi. Peranan hubungan antar pribadi dibagi atas tiga peranan penting diantaranya :

a. Peranan sebagai figurehead.

Sebagai konsekuensi dari status dan otoritas formal yang dimiliki, seorang pemimpin diharuskan untuk melakukan tugas - tugas simbolik tertentu yang bersifat legal dan sosial. Diantaranya menandatangani dokumen - dokumen yang berhubungan dengan program pembangunan masyarakat, memimpin setiap pertemuan - pertemuan dalam membicarakan program pembangunan masyarakat baik dari perencanaan hingga pada tahap pelaksanaan dan evaluasi program pembangunan tersebut.

b. Peranan sebagai pemimpin (leader).

Dalam mewujudkan peranan ini pemimpin berperan aktif dalam melakukan hubungan interpersonal dengan kelompok / masyarakat yang dipimpin, dengan melakukan kegiatan memimpin, memotivasi, mengembangkan dan mengendalikan. Pelaksanaan pembangunan dengan melibatkan banyak orang tentulah sangat dibutuhkan pendekatan interpersonal seorang pemimpin. Dengan pendekatan ini suatu kelompok / masyarakat mendapatkan perhatian yang baik dari pemimpin dan merasa memiliki peranan dalam melaksanakan pembangunan tersebut.

c. Peranan sebagai pejabat perantara (liaison manager)

Hakikat dari peranan sebagai pejabat perantara (liaison manager) adalah membuat kontak - kontak atau relasi yang baru sehingga dengan relasi baru yang berada diluar kelompok / masyarakat menjadi bantuan yang berarti ketika pelaksanaan pembangunan tersebut berhubungan dengan kelompok / masyarakat luar karena biasanya segala hal yang berhubungan dengan orang lain akan lebih cepat penyelesaiannya ketika pemimpin dan masyarakat luar sudah saling mengenal.

2. Peranan yang berhubungan dengan informasi (informasional role)

Pelaksanaan program pembangunan masyarakat tidak terlepas dari informasi informasi yang dibutuhkan dalam pelaksanaan pembangunan tersebut baik sifatnya 
teknis maupun non teknis agar dapat berjalan secara efektif dan efisien. Maka seorang pemimpin selain menjalankan peranan hubungan antarpribadi juga berperan dalam mempersiapkan segala informasi yang dibutuhkan. Peranan ini dapat dijabarkan antara lain :

a. Peranan sebagai pemantau (monitor)

Sebagai seorang pemimpin diharapkan secara kontinu mencari informasi sejumlah sumber - sumber yang telah dan akan berjalan baik dari pertemuan pertemuan masyarakat, segala hal saran dan keluhan masyarakat, ataupun pada saat melakukan perjalanan pengamatan. Dari informasi - informasi tersebut pemimpin dapat menganalisis masalah - masalah yang terjadi, peluang - peluang dan untuk mengembangkan tindak lanjut dari peristiwa - peristiwa luar serta proses internal dalam kelompok / masyarakat.

b. Peranan sebagai disseminator (pembagi informasi)

Informasi yang didapatkan seorang pemimpin baik yang sifatnya aktual dan beberapa diantaranya berhubungan dengan preferensi dari masyarakat yang ingin mempengaruhi pemimpin tersebut. Sehingga informasi tersebut sebainya diteruskan kepada kelompok / masyarakat yang membutuhkan informasi sehingga tugas pada masing - masing bagian dari struktur organisasi yang telah dibuat dapat berjalan secara efektif dan efisien.

c. Peranan sebagai juru bicara (Spokesman)

Sebagai seorang pemimpin yang bertindak atas nama organisasi maka dibutuhkan peranan sebagai juru bicara terhadap permasalahan - permasalahan yang terjadi dalam pelaksanaan program pembangunan masyarakat tersebut. Pemimpin juga memposisikan dirinya sebagai pusat informasi sehingga dibutuhkan pemimpin dapat menyaring dan menyampaikan informasi - informasi dengan baik sehingga pelaksanaan pembangunan dapat berjalan.

3. Peranan Pembuat Keputusan (Decision role)

Peranan yang paling sulit yang dijalankan seorang pemimpin dan sangat dibutuhkan kelompok / masyarakat dalam menjalankan program pembangunan masyarakat adalah bagaimana seorang pemimpin terlibat langsung dalam pengambilan keputusan terhadap program pembangunan yang akan dijalankan. Hal ini berkaitan dengan fungsi pemimpin yang paling bertanggung jawab terhadap program yang akan dijalankan sehingga pemimpin juga akan bertanggung jawab terhadap keputusan - keputusan yang akan diambil. Peranan dalam pembuat keputusan dapat dijabarkan diantaranya :

a. Peranan sebagai wirausaha (entrepreneur)

Peranan ini yang dimaksudkan adalah seorang pemimpin bertindak sebagai pemrakarsa dan perancang perubahan yang terkendali untuk memanfaatkan peluang - peluang dalam memperbaiki situasi yang ada sekarang sehingga dengan peranan ini diharapkan pemimpin dapat terlibat langsung dalam pengambilan keputusan terhadap program pembangunan yang akan dijalankan dalam merubah keadaan yang ada menuju pembangunan yang tepat sasaran bagi masyarakat.

b. Peranan sebagai penghalau gangguan (disturbance handler)

Pelaksanaan program pembangunan masyarakat biasanya tidak berjalan sesuai dengan perencanaan yang ideal, hal - hal yang bersifat krisis yang mendadak yang tidak dapat diabaikan baik berupa konflik internal atau eksternal yang terjadi pada kelompok / masyarakat yang akan menggangu pelaksanaan program pembangunan. Sehingga, peranan pemimpin dapat mengambil keputusan 
dalam menangani permasalahan - permasalahan konflik yang terjadi sehingga gangguan yang terjadi dapat teratasi dengan baik.

c. Peranan sebagai pembagi sumber daya (rsource alligator)

Membagi sumber daya adalah salah satu bentuk pengambilan keputusan yang dapat dijalankan seorang pemimpin. Pengalokasian sumber daya yang dimiliki organisasi baik dana, personalia, material, peralatan, fasilitas - fasilitas, dan jasa - jasa untuk menjalankan program pembangunan masyarakat secara efisien dan efektif sangat dibutuhkan kelompok / masyarakat sehingga pemimpin memiliki peranan ini untuk mengatur dan memberdayakan sumber daya yang ada secara baik sehingga pelaksanaan pembangunan dapat berjalan sesuai perencanaan yang ada. Dalam pengalokasian sumber daya tersebut pemimpin sebaiknya memiliki strategi yang harus ditetapkan, pandangan - pandangan yang jauh dan positif harus diperhatikan oleh seorang pemimpin.

d. Peranan sebagai seorang perunding (negosiator)

Seorang pemimpin juga memiliki peranan yang penting dalam menyukseskan program pembangunan masyarakat melalui perundingan perundingan baik internal maupun eksternal dari kelompok / masyarakat sehingga pelaksanaan pembangunan dapat berjalan dengan baik.

\section{Kesimpulan}

Dalam penjelasan diatas dapat ditarik beberapa kesimpulan yang penting untuk diketahui dan dilaksanakan dengan seksama bagi seorang pemimpin dalam menjalankan program pembangunan masyarakat yaitu :

a. Pemimpin memiliki 2 (dua) fungsi utama dalam melaksanakan program pembangunan masyarakat yaitu fungsi yang berhubungan dengan tugas (task related) atau pemecahan masalah dan fungsi pemeliharaan kelompok (group maintenance).

b. Langkah - langkah dalam melaksanakan pembangunan masyarakat yaitu perencanaan, pengorganisasian, pengawasan, dan evaluasi kegiatan.

c. Peranan pemimpin dalam pembangunan masyarakat diantaranya :

1. Peranan hubungan antar pribadi (interpersonal role) yang diwujudkan dalam peranan sebagai figurehead, pemimpin dan pejabat perantara (liaison manager)

2. Peranan yang berhubungan dengan informasi (informasional role) yang diwujudkan dalam peranan sebagai pemantau (monitor), sebagai pembagi informasi (disseminator), dan juru bicara (spokesman).

3. Peranan pembuat keputusan (Decision role) yang diwujudkan dalam peranan sebagai wirausaha (entrepreneur), penghalau gangguan (disturbance handler), pembagi sumber daya (resource alligator) dan sebagai perunding (negosiator).

5. Daftar Pustaka

[1] Adisasmita, Rahardjo. (2006) , Pembangunan Pedesaan dan Perkotaan, Graha Ilmu, Yogyakarta.

[2] Aisyah, Sitti, and Soltan Takdir. (2017), Implementasi Gaya Kepemimpinan Situasional Kepala Sekolah Di Smp Negeri 1 Wamena Kabupaten Jayawijaya, Jurnal Kepemimpinan dan Pengurusan Sekolah,Vol.2 No.2 , 119 - 132. 
[3] Budiman, Arif . (1997), Teori Pembangunan Dunia Ketiga, PT. Gramedia, Jakarta.

[4] Kogoya, Undinus. (2013) , Peranan Kepemimpinan Kepala Suku Dalam Mengatasi Konflik Antara Suku Dani Dan Suku Damal Di Kabupaten (Suatu Studi Di Mimika Provinsi Papua), Jurnal Politico, Vol.1 No.3, 1-15

[5] Nelfan, Devin, and Meilinda Setiawati. (2014), Analisis Pengaruh Lingkungan Kerja, Kepemimpinan, Dan Motivasi Terhadap Kepuasan Kerja Karyawan Food and Beverage "X" Hotel Surabaya. Jurnal Hospitality dan Manajemen Jasa Vol.2 No.1, 127-145.

[6] Pasolong, Harbani .(2010), Kepemimpinan Birokrasi, Alfabeta, Bandung.

[7] Rivai, Veithzal, and Deddy Mulyadi. (2010), Kepemimpinan dan Perilaku Organisasi . Rajawali Press, Jakarta

[8] Thoha, Miftah. (2006), Kepemimpinan dalam Manajemen, PT. Raja Grafindo Persada, Jakarta.

[9] Yukl, Gary. 1998. Kepemimpinan dalam Organisasi ( Edisi Bahasa Indonesia), Prenhallindo, Jakarta. 